\title{
Faculty of Marine Science and Fisheries- An Institute of Ocean Research
}

\author{
Md. Simul Bhuyan* \\ Faculty of Marine Science and Fisheries, University of Chittagong, Bangladesh
}

Submission: November 15, 2018; Published: December 03, 2018

*Corresponding author: Simul Bhuyan, Faculty of Marine Science and Fisheries, University of Chittagong, Bangladesh

\section{Introduction}

Faculty of Marine Science and Fisheries is a pioneer academic marine research institute in Bangladesh. This institute was established in 1971 with the name of "Department of Marine Biology and Oceanography". The department was converted into Institute of Marine Sciences in 1983 by the University of Chittagong. Since then this institute has a major contribution in the marine science study. The professors and students of this institute have great contribution in the ocean resources study. There is some well-organized laboratory in the Institute for ocean resources study. These labs include Dr. Nuruddin Mahmud Oceanography Lab., Fisheries Lab., Dr. Yusuf Sharif Ahmed Khan Environmental Pollution Lab., Nutrition Lab., Plankton, and Ecology Lab. The institute focuses on the multidisciplinary studies and pledges to produce highly trained graduates. The graduates are devoted to using their skill in marine science and its related disciplines. Besides oceanic science, it also emphasizes the brackish water environment. This faculty is now emphasized on the following topics of the ocean.

\section{Marine science branch}

Marine Ecology, Marine Invertebrates, Marine Chordates \& Ichthyology, Marine Botany, Marine Microbiology, Physical Oceanography, Chemical Oceanography, Estuarine Processes, Wetland and Lake Management, Mangrove Ecosystem \& Management, Planktology, Environmental Pollution, Environmental Impact Assessment, Biodiversity \& Conservation, Fisheries Resource Management, Fish Breeding \& Genetics, Biochemistry \& Physiology, Fish Health Management, Fish \& Shrimp Nutrition \& Feed Management, Aquaculture, Aquaculture Planning \& Engineering, PostHarvest Technology, Sustainable livelihood Approach, Remote Sensing \& GIS, Research Methodology, Biostatistics. Practices in Computer Application, Communicative English, Mathematics.

\section{Oceanography branch}

Marine Ecology, Physics, Chemistry, Marine Resources, Computer and Programming, Marine Microbiology, Communicative English, Physical Oceanography, Chemical Oceanography, Biological Oceanography, Hydrography, Mariculture, Fisheries Oceanography, Coastal Morphology and
Processes, Applied Mathematics, Geological Oceanography, Marine Biogeochemistry, Marine Environmental Management, Hydrocarbon exploration and Seismology, Fluid Mechanics and Sediment transport, Remote Sensing of the Oceans, Research tools in Oceanography, Applied Statistics, Ocean Forecasting and Meteorology, Oil, Gas and Renewable Energy from the Oceans, Modelling Marine Processes, Marine Geophysics, Port Management and Maritime Logistics, Seamanship and Maritime Navigation, Research Methodology, Law of the Sea.

\section{Fisheries branch}

Introduction to Fisheries Resources, Aquatic Ecology, Aquatic invertebrates, Ichthyology and Systematics, Aquatic Botany, Planktology, Fisheries Microbiology, Fish Physiology and Endocrinology, Fish Pharmacology, Communicative English, Fish and Shell Fish Biology, Aquaculture, Hatchery Operation and Management, Genetics and Fish Breeding, Estuarine and Coastal Fisheries, Reef Fisheries, Oceanography, Computer Application, Remote Sensing Theories and Application, Mathematics, Fish Population Dynamics, Aquatic Animal Health and Management, Fish and Shell Fish Nutrition, Biodiversity Conservation and Management, Wetland and Lake Management, Integrated Coastal Zone Management, Fish Processing Technology, Fisheries Economics, Environmental Pollution, Bio-statistics, Fisheries Resources Management, Aquaculture Planning and Engineering, Mangrove Fisheries and Management, Fish Feed Technology, Climate Change and Fisheries, Applied Geographical Information Systems, Environmental Impact Assessment, Fisheries Conservation and Laws, Research Methodology.

Now, there is five branch in masters' level there are some branches in the faculty: Fisheries, Aquaculture, Environmental Pollution, Oceanography, Fish Processing \& Microbiology. This institute has world recognized scientists and their work are being published in the leading journal of the world. It belongs to a well-equipped field research station located in Cox's Bazar. It is basically used for in situ marine data collection and research in the ocean. The institute has a rich library named Dr. Abdul Latif Bhuyan Seminar Library. It has a great collection of books, journals magazines and other academic and research supplements with all modern amenities. Beside enriched library, 
it has a well-established Marine Biology Museum. It has a good collection of marine and coastal life forms. The graduates of this institute are a gem of the country who provide their skill in the fields of marine sciences, fisheries, and aquaculture. They also contribute toward research, management, fisheries, and aquaculture business environment. Their research outputs and knowledge are great resources for the country as well as for the world. Every year many students go for a higher degree in overseas reputed university with scholarship. It is high time

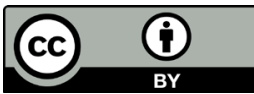

This work is licensed under Creative Commons Attribution 4.0 License DOI: 10.19080/IJESNR.2018.15.555915 for the government to provide more funding facilities for this institute to fulfill the dream of the blue economy.

\section{References}

1. http://www.cu.ac.bd/

2. http://en.wikipedia.org/wiki/Institute_of_Marine_Sciences_and_ Fisheries/

3. http://www.imscu.ac.bd/

4. http://en.bdfish.org/2012/02/institute-marine-sciences-fisheries$\mathrm{cu} /$

Your next submission with Juniper Publishers will reach you the below assets

- Quality Editorial service

- Swift Peer Review

- Reprints availability

- E-prints Service

- Manuscript Podcast for convenient understanding

- Global attainment for your research

- Manuscript accessibility in different formats ( Pdf, E-pub, Full Text, Audio)

- Unceasing customer service

Track the below URL for one-step submission https://juniperpublishers.com/online-submission.php 